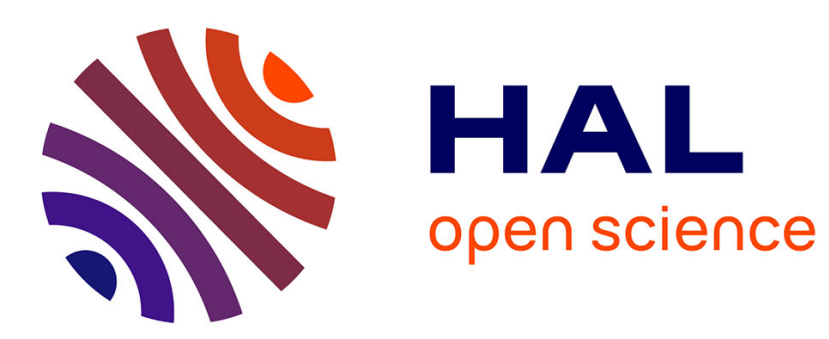

\title{
A qualitative analysis of rising tones in Dublin English
}

Julia Bongiorno, Sophie Herment

\section{To cite this version:}

Julia Bongiorno, Sophie Herment. A qualitative analysis of rising tones in Dublin English. 9th international conference on Speech Prosody, Jun 2018, Poznan, Poland. hal-01814067

\section{HAL Id: hal-01814067 \\ https://hal.science/hal-01814067}

Submitted on 15 Jun 2018

HAL is a multi-disciplinary open access archive for the deposit and dissemination of scientific research documents, whether they are published or not. The documents may come from teaching and research institutions in France or abroad, or from public or private research centers.
L'archive ouverte pluridisciplinaire HAL, est destinée au dépôt et à la diffusion de documents scientifiques de niveau recherche, publiés ou non, émanant des établissements d'enseignement et de recherche français ou étrangers, des laboratoires publics ou privés. 


\title{
A qualitative analysis of rising tones in Dublin English
}

\author{
Julia Bongiorno \& Sophie Herment \\ Aix-Marseille University, Laboratoire Parole et Langage, CNRS UMR 7309, France \\ julia.bongiorno@lpl-aix.fr; sophie.herment@univ-amu.fr
}

\begin{abstract}
In this paper, we present the results of a preliminary study of the intonation system of Dublin English (DE) with a particular focus on rising tones. After analysing a corpus recorded in the framework of the PAC Program, we conclude that Dublin English has a hybrid intonation system that mixes standard English contours like falls and rises, and Northern Irish contours like rise-falls. Rising declaratives are also found (as reported by [7] and [8]), but we argue that some of these rising tones are occurrences of Uptalk and do not belong to the Urban Northern British Intonation (UNBI) that is found in Belfast. Indeed the analysis of extracts of conversations providing an ecological context makes it possible to perform a qualitative study of the interactional and pragmatic functions linked to Uptalk, and this is, as far as we know, the first study of the kind on Dublin English rising tones. We conclude that UNB rises take the form of rise-plateaus in DE. Continuation rises can be realized as rise-plateaus or low rises, while uptalk takes the form of full rises and high rises.
\end{abstract}

Index Terms: Dublin English, rising contours, uptalk, interactional functions of intonation, phonetic form.

\section{Introduction}

This paper focuses on the variety of English spoken in the Republic of Ireland, namely Southern Hiberno English [1], and more specifically in Dublin, which we will refer to as Dublin English (DE) hereafter. The segmental characteristics of Southern Irish English have been widely described (see amongst others [1], [2], [3]), and [4] studied DE more particularly. However, the prosodic characteristics are hardly ever mentioned. [5] have studied the intonation of four dialects of Ireland, but have not analysed DE. [6] writes that "the intonation of (Southern) Irish English is not strikingly different from that of RP". This might explain why it has received so little attention. [7] have looked at tonal alignment in three dialects of Hiberno-English: Donegal, Drogheda and Dublin. They report that declaratives are mainly realised $\mathrm{H}^{*} \mathrm{~L}$ in Dublin, with an alignment of $\mathrm{H}^{*}$ fixed at VC boundary. In the framework of the IViE project, recordings were performed in Dublin and [8] confirms that the intonation in Dublin is not much different from that of Cambridge and reports that "rising declaratives are possible, but not particularly common" (only 6\% in Dublin). [7] and [8]'s findings, however, are based on read speech. [8] analysed 22 phonetically controlled sentences with a range of grammatical structures (declaratives, yes-no questions, wh-questions, and declarative questions).

In this paper, we propose to give a brief preliminary overview of the intonation system found in DE, and to focus on rising intonations, on the basis of a corpus recorded in Dublin by the first author in the framework of the PAC project [9]. For the purpose of the study, we base our findings on the close analysis of a few sentences and the context in which they appear. Our analysis is therefore mainly qualitative.

\section{Corpus and method}

\subsection{The PAC Project}

The PAC Project (Phonologie de l'Anglais Contemporain, [9]) was initiated in 2004. It aims at describing the English(es) spoken around the world from a systematic and comparative point of view. The main goal of this program is to create an interdisciplinary database of different varieties of spoken English in order to allow specialists of several disciplines to study and compare them. In 2016, around 40 researchers were part of the program, and 37 corpora had been collected (several cities in England, Australia, New-Zealand, Singapore, India...).

All the recordings in the PAC program follow a common protocol:

- 2 word lists (one for vowels, one for consonants);

- a text;

- a formal conversation in two parts led by the researcher: the first part is a questionnaire about the origins and personal information of the speaker, and the second part is the LVTI questionnaire (Langue, Ville, Travail, Identité -Language, Urban life, Work, Identity-[10]), with questions about work and urban life, leading to a thematic conversation about their work life, some of their thoughts about the city they live in and their perception of the variety of English they speak.

- a free informal conversation recorded by a third party in the absence of the researcher in order to avoid the paradox of the observer ([11]).

\subsection{The PAC Dublin corpus}

Recordings were performed in Dublin in 2016 ([12]): the corpus is composed of 10 native speakers of English between 24 and 78 who were born and have spent their whole life in Dublin. They all live south of the river Liffey (a part of Dublin also called Southside) and are either employed or retired (see Table 1). They all belong to the same social network: family or close friends who have known each other for decades. The recordings took place at the informants' places so that felt as comfortable as possible.

Table 1: Informants

\begin{tabular}{|c|c|c|c|c|}
\hline Activity & Speaker & Age & Sex & Job/studies \\
\hline \multirow{3}{*}{$\begin{array}{c}\text { Young } \\
\text { workers } \\
\text { First job }\end{array}$} & BB1 & 24 & $M$ & Retail \\
\hline & SK1 & 27 & $\mathrm{~F}$ & Doctor \\
\hline & RCL1 & 32 & $\mathrm{~F}$ & Music toacher/art \\
\hline \multirow{2}{*}{$\begin{array}{l}\text { People who } \\
\text { have been }\end{array}$} & RF1 & 43 & M & IT engineer \\
\hline & TC1 & 58 & $\mathrm{~F}$ & Costume designer \\
\hline
\end{tabular}




\begin{tabular}{|c|c|c|c|c|}
\hline \multirow{3}{*}{$\begin{array}{l}\text { working } \\
\text { for more than } \\
20 \text { years }\end{array}$} & FK1 & 58 & $\mathrm{~F}$ & Craftsperson \\
\hline & $\mathrm{MC} 1$ & 63 & $\mathrm{M}$ & Music teacher \\
\hline & FS1 & 74 & $\mathrm{~F}$ & Irish teacher \\
\hline \multirow{2}{*}{$\begin{array}{l}\text { Retired } \\
\text { people }\end{array}$} & MM1 & 75 & $\mathrm{~F}$ & Retail / cook \\
\hline & $\mathrm{CC} 1$ & 78 & $\mathrm{~F}$ & Tailoress \\
\hline
\end{tabular}

\subsection{Method}

For the pilot study presented here, only the thematic conversations were analysed (LVTI questionnaires on work and urban life, see 2.1). They were not recorded by the first author but by a relative or friend of the informant who is also a Dubliner and who asked the questions The corpus analysed amounts to more than $1 \mathrm{~h} 15 \mathrm{mns}$ of recording (mean $7.30 \mathrm{mns}$ per speaker).

\subsubsection{Extraction of utterances}

An auditory analysis was performed first, passages were selected by the authors as follows: for each speaker, 10 declaratives with a falling contour, 10 declaratives with a rising contour, 10 incomplete sentences with a falling contour, 10 incomplete sentences with a rising contour, emphatic segments and yes-no questions were extracted. For the last two categories, it was impossible to find 10 occurrences, so only a few were extracted. These segments of speech were analysed through PRAAT [13]. Due to the subjective mode of selection and the lack of data for some categories, no quantitative analysis could be performed.

\subsubsection{Automatic annotation and detection errors}

In order to automatically annotate the extracted utterances, we used SPPAS [14], and Momel \& Intsint [15].

The annotation, however, was not always reliable because of some background noises that could not be avoided due to the fact that we only studied conversations. Figure 1 below shows an example where detection errors are obvious: the second tier on the figure contains the Hertz values as extracted by Momel and the third tier shows the corresponding Intsint coding. B stands for Bottom and $\mathrm{T}$ for Top. The two T target points are obviously erroneous if we look at the F0 curve and the pitch settings. This is due to a background noise that is perceivable when listening to the sound file. The annotations were therefore all manually corrected.

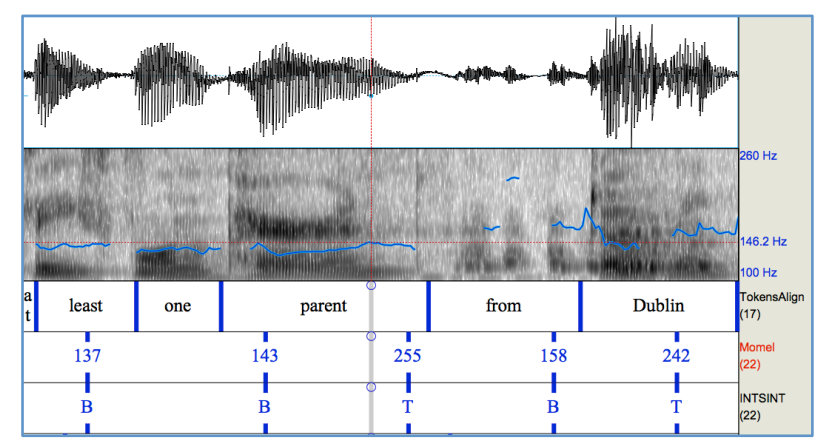

Figure 1: Detection errors

\section{Intonation system in Dublin: preliminary results}

Our preliminary results, based on auditory impressions and PRAAT analysis, show that both falling and rising contours in
DE sound like General British (GB) intonation ([30]). This confirms [7] and [8]'s conclusions. We also found contours that are not present in GB intonation, such as rise-plateaus (that are present in Belfast English, see [16]), rise-plateauslumps, and rise-falls.

\subsubsection{Rise-plateaus}

A rise-plateau is characterised by a rise on the nuclear syllable and the following syllables uttered on a relatively high plateau. When there are no post-nuclear syllables, the rise and the plateau occur on the nuclear syllable as in figure 2 below (rise and plateau on sea):

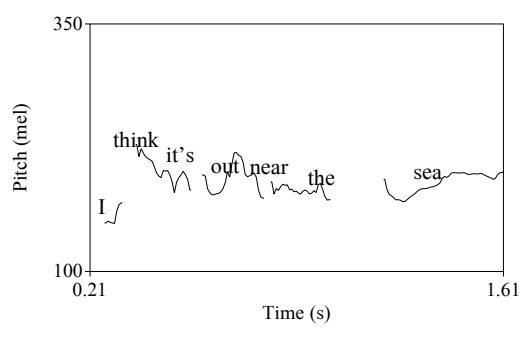

Figure 2: Rise-plateau (speaker CC1)

\subsubsection{Rise-plateau-slumps}

Rise-plateau-slumps are also present in DE. Like rise-plateaus, they typically show a rise on the nuclear syllable, a high plateau, but then a fall on the last syllable that does not go down to the bottom level (see figure 3, where the rise and the plateau are on should and the slump takes place on be).

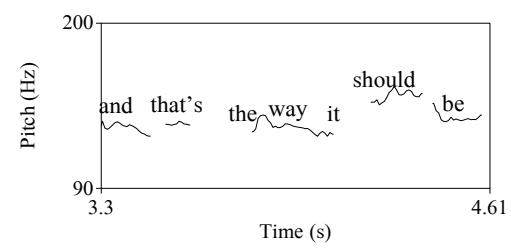

Figure 3: Rise-plateau-slump (speaker FS1)

\subsubsection{Rise-falls}

Rise-falls are also found in DE, in emphatic contexts mostly, where GB speakers are likely to realise a fall-rise. In rise-falls (Figure 4), the starting point of the rise and the end of the fall are at the same level and the rise is sharper than in the riseplateau-slump.

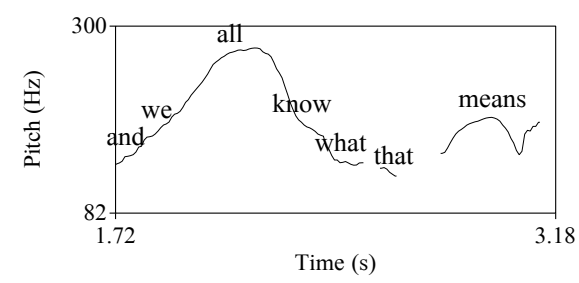

Figure 4: Rise-fall (speaker FK1)

\subsubsection{Partial conclusion}

Dubliners, like speakers of Mid-Ulster English, use riseplateaus and rise-plateau-slumps on declaratives and rise-falls 
on emphasis, along with falling and rising contours similar to those of GB.

We conclude that the intonation system of DE is a hybrid one that mixes standard English contours and Northern Irish ones, like the UNB rises on declaratives. Hybrid intonational systems exist in other varieties of English: [17] mentions biintonational speakers who alternate between rises and falls in declarative sentences, the criteria for choosing between a rise and a fall being unknown to the best of our knowledge. This could be the final point of the analysis. However, in DE, some of the rises found on declaratives seem to have stylistic and interactional functions. Our hypothesis is therefore that in DE some of the rises on declaratives are occurrences of uptalk and not UNB rises. The next section focuses on rising tones.

\section{Focus on rising tones}

Rises on declaratives are the default intonation in UNB varieties of English (see [17]) like Ulster English [18] (and also amongst others Glasgow English [19, 20], Liverpool English [21] or Manchester English [22]): they have a systemic function. In DE, these types of rises on declaratives occur, along with rises that seem to be occurrences of uptalk.

The phenomenon of uptalk is acknowledged in Irish English as a recent innovation, but no scientific study was led on the subject [23]. We hypothesize that not all the rising contours are occurrences of uptalk and that three different types of rising contours exist in DE: uptalk, UNB rises, and continuation rises (similar to question rises). The first type has pragmatic functions, the second type is used on declaratives as a feature similar to Belfast English, and the last occurs on incomplete parts of speech (and yes-no questions). We deal in the rest of the paper with the interactional functions and the phonetic form of the rising contours in our corpus.

\subsection{Interactional functions}

Most authors agree that uptalk has interactional functions but disagree about those functions. To sum up, [23, p. 68] writes: "it [uptalk] is used for checking and for seeking feedback [...]. It asks 'Are you following me?'. It shares rather than tells." In our corpus, some occurrences seem to be uptalk in that respect.

Some rises seem to be used for seeking feedback, and for asking confirmation to the interviewer:

And people from all over the country that have very soft accents, and I like to think that I am probably one of them (RCL1)

The speaker (RCL1, a 32 year-old woman artist and music teacher, see table 1) talks about the different accents she heard in Ireland. The contour on the underlined part is rising, probably because the speaker asks for confirmation and asks if her accent is as soft as she thinks it is. In this case, the rising tone is an occurrence of uptalk and its function is seeking confirmation.

Rising contours on declaratives are also largely used by the speakers in our corpus for checking if what they say is what the interviewer is expecting from them (see [24] and [25]). In our recordings, people talk about themselves and give information that the interviewer already knows (work life, personal life...), so the rising tone sounds as if the speaker apologised for that or as if they checked if what they say is what is expected.
So I work as a pediatric doctor in Tallaght hospital at the moment. (SK1)

So I'm a guitar teacher. (MC1)

In both situations, the interviewer is a relative of the speaker, so they already have the piece of information.

\subsection{Phonetic form}

The phonetic form of uptalk varies according to the variety of English [26], and there is little agreement concerning its shape [23]. For instance, [27] report that the contour of Australian uptalk is $\mathrm{L} * \mathrm{H}-\mathrm{H}$ or $\mathrm{H} * \mathrm{H}-\mathrm{H} \%$, while for Glasgow it is $\mathrm{L} * \mathrm{H} H-$ L\%. [28] distinguishes 5 different contours for uptalk: high rise, full rise, low rise, low flat, and fall-rise. According to [23] the only elements that are common to most forms of uptalk are the fact that the average pitch levels are lower, the rise starts later and from a lower level, thus resulting in a more dramatic rising pattern for uptalk than for questions.

\subsubsection{Phonetic form of uptalk in $D E$}

We analysed several occurrences that we classified as uptalk in our corpus because they had interactional functions, and found several full-rise tones, in which the starting point of the rise is lower than the preceding syllables (Figure 5):

- Do you feel like you're a true Dubliner?

- Yes. Shall I expand on that? Er well I was born in Dublin, I've always lived in Dublin, er I don't know. (SKI)

In this example, the speaker (SK1) is asked whether she feels she is a true Dubliner or not. This is a good example of uptalk, because SK1 gives her opinion, and at the same time she asks the interviewer if being born in Dublin and having lived there her whole life is enough to be considered a 'True Dubliner'.

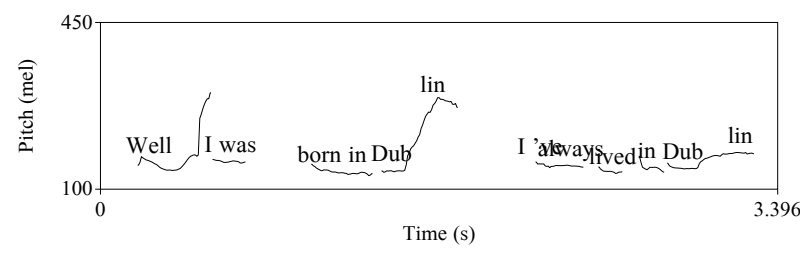

Figure 5: Full rise

We also found occurrences of high rises, where the starting point of the rise is rather high in the pitch range (Figure 6)

As you know I've just come back from India where I took 2000 odd photos (RF1)

Here, the speaker (RF1) is being interviewed by his partner's uncle (MC1), who already knows he went to India and took pictures but he probably doesn't know about the crazy number of pictures and the rising tone sounds as if RF1 was expressing something like "Can you believe this? I know it's crazy."

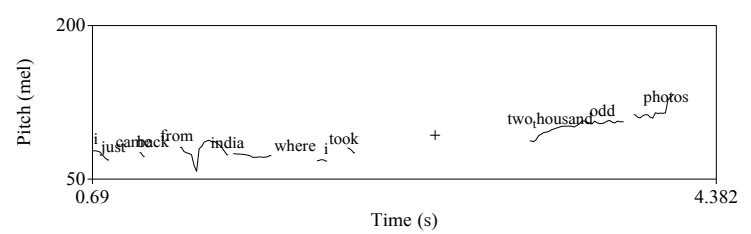

Figure 6: High rise 
4.2.2. Phonetic form of continuation rise (and yes-no rise) in $D E$

Most studies dealing with uptalk compare the uptalk contour to that of yes-no questions (see [23] amongst others). It is also interesting to compare uptalk contours to rising contours found in incomplete sentences. In DE, as in Standard English, low rises are realised for both categories (Figures 7 and 8):

So if anything is in cyclable distance from the city center or where I need to go to work then that's a really big advantage (RCL1)

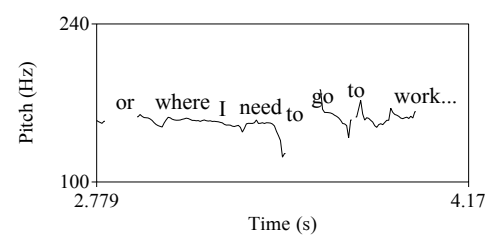

Figure 7: Low rise in an incomplete sentence

Is there anything you'd like to talk about?(MC1)

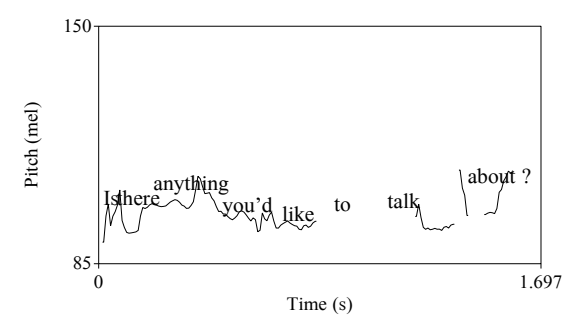

Figure 8: Low rise in a yes-no question

For incomplete statements, a rise-plateau can also be heard, and for yes-no questions we found rise-plateau-slumps too, but the latter will not be taken into account since they are not strictly rising contours but rather rising-falling (even though slightly) contours.

\section{Discussion}

Our hypothesis was that in DE three different types of rising contours existed: uptalk, UNB rises, and continuation rises (similar to question rises). We analysed the phonetic form of those rising contours, and it turns out that in our DE data, four different forms can be distinguished:

- Rise-plateau

- Low rise

- Full rise

- High rise

Rise-plateau is found on declaratives in DE. Rise-plateau is also used in incomplete statements, along with low rise, showing non-finality, while full rise and high rise are used as uptalk contours to convey interactional/pragmatic functions as discussed in 4.1. However, it is sometimes difficult to say whether a rising contour corresponds to an uptalk contour or a continuation contour, as in the example below (Figure 9). Does the first rise (on West Meath) indicate non finality, or does the speaker (FS1) use an uptalk rise because the interviewer (her friend) already knows that she lived in West Meath (in this case, she could be using uptalk to apologise because she is giving a piece of information that is already known, see 4.1)?

I was out of Dublin for 6 years, I lived in West Meath uhm in the sixties so I don't know whether that had any influence on, you know the way that you would be. (FS1)

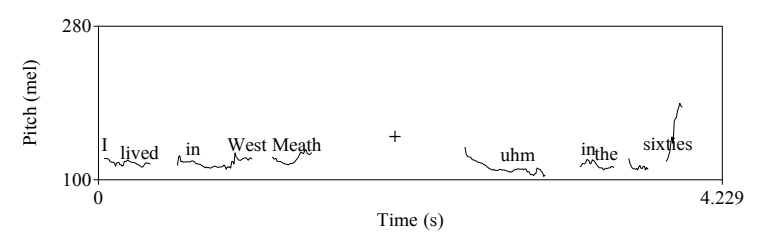

Figure 9: uptalk or continuation contour?

The contour on West Meath is a rise plateau. Our results would therefore tend to favour a continuation rise here.

On the contrary, the second rise, on sixties, is clearly a case of uptalk: it integrates the question which the speaker makes explicit just afterwards, wondering if the fact that she lived in West Meath can have any influence on the way she speaks and almost asking her co-speaker's opinion. The contour is a full rise. This is interesting because speaker FS1 is aged 74 , which would tend to go against the idea that uptalk is a recent innovation in DE (unless FS1 has taken up uptalk contours recently, which seems rather improbable).

\section{Conclusion \& perspectives}

To the best of our knowledge, our study is the first to analyse DE rising contours in conversations. It is also the first to try and describe the variation present in DE intonational system. The present analysis, although a pilot study, shows that the intonational system of DE is a hybrid one, mixing Northern Irish contours like rise-falls and UNB contours like riseplateaus and rise-plateau-slumps on declaratives, with more standard contours like low falls and low rises. Our results tend to show that UNB rises take the form of rise-plateaus in DE and that continuation rises can be realized as rise-plateaus too or low rises. Our study also attests that uptalk is present in DE, that it is probably not a recent innovation, and that it takes the form of full rises and high rises, which correlates [28]'s findings on uptalk contours by a Derry speaker. Uptalk in DE would have the same phonetic forms as in Ulster English. Our study also confirms [29]'s conclusions that uptalk contours are not restricted to high rise. This needs further analysis and our aim in the near future is to extend the PAC Dublin corpus, analyse extracts from both the formal and informal conversations and elaborate a robust method of extraction and annotation so as to be able to provide a detailed description of the intonation system of Dublin English and perform a quantitative analysis of rising contours. Our present data show considerable inter-speaker variation: different speakers are likely to use different intonation patterns for the same purpose. It would be interesting to see whether intonational variation is correlated to a speaker's profile taking into consideration factors like age, social origins, areas of the city where the speaker lives (see [4]'s local vs. non-local varieties), but also factors linked to the identification of the speaker with their city (see [4]'s profiles of mainstream and fashionable Dubliners). 


\section{References}

[1] J. Harris, Phonological variation and change. Studies in Hiberno-English. Cambridge: Cambridge University Press, 1985.

[2] R. Hickey, "Irish English: phonology," in A Handbook of Varieties of English, B. Kortmann and E.W. Schneider, Eds. New-York: Mouton de Gruyter, 2004, pp. 68-97.

[3] E. Ferragne and F. Zumstein, "La République d'Irlande," in $\mathrm{La}$ prononciation de l'anglais contemporain dans le monde: Variation et structure, I. Brulard, J. Durand, and P. Carr, Eds. Toulouse: Presses Universitaires du Midi, 2015, pp. 199-213.

[4] R. Hickey, "Dublin English: current changes and their motivation," in Urban voices, P. Foulkes and G. Docherty, Eds London: Edward Arnold, 1999, pp. 265-81.

[5] M. Dalton and A. Ní Chasaide, "Nuclear Accents in Four Irish (Gaelic) Dialects", in Proceedings of ICPhS XVI, 2007, pp. 965968.

[6] J. Wells, Accents of English. Cambridge: Cambridge University Press, 1982

[7] R. Kalaldeh, A. Dorn, and A. Ní Chasaide, "Tonal Alignment in Three Varieties of Hiberno-English," in Proceedings of Interspeech, 2009, vol. 4, pp. 2427-2430.

[8] E. Grabe, "Intonational variation in urban dialects of English spoken in the British Isles," in Regional Variation in Intonation, P. Gilles and J. Peters, Eds. Tübingen: Niemeyer, 2004, pp. 931. http://www.phon.ox.ac.uk/files/apps/IViE/

[9] P. Carr, J. Durand, and M. Pukli, "The PAC Project: Principles and Methods," La Tribune Internationale des Langues Vivantes, no. 36, pp. 24-35, 2004. http://www.projet-pac.net

[10] A. Przewozny, J.-M. Tarrier, H. Giraudo, and J. Durand, "Language, Urban life, Work, Identity: Ways and Means," presented at the PAC 2013 Conference, Spoken English Corpora: from annotation to interphonologies, May 312013 , Aix-Marseille University, France, 2013.

[11] W. Labov, Sociolinguistic Patterns, Philadelphia: University of Pennsylvania Press, 1972.

[12] J. Bongiorno, "Etude du système phonologique de l'anglais parlé à Dublin dans le cadre du programme PAC," Masters Degree Thesis, Aix-Marseille University, Aix-en-Provence, 2017.

[13] P. Boersma, and D. Weenink, "PRAAT, a system for doing phonetics by computer," Glot International 5(9/10), pp. 341345, 2001. http://www.praat.org

[14] B. Bigi, "SPPAS - Multi-lingual Approaches to the Automatic Annotation of Speech," The Phonetician, vol. 111-112, no. I-II, pp. 54-69, 2015.

[15] D. J. Hirst, "A Praat plugin for Momel and INTSINT with improved algorithms for modeling and coding intonation," in Proceedings of ICPHS XVI, 2007, pp. 1233-1236.

[16] G. Turcsan and S. Herment, "L'anglais du Nord de l'Irlande," in La prononciation de l'anglais contemporain dans le monde. Variation et structure, I. Brulard, J. Durand, J., and P. Carr, Eds. Toulouse: Presses Universitaires du Midi, 2015, pp. 183-198.

[17] A. Cruttenden, Intonation, $2^{\text {nd }}$ edition ( $1^{\text {st }}$ edition 1986), Cambridge: Cambridge University Press, 1997.

[18] E. Jarman and A. Cruttenden, "Belfast intonation and the myth of the fall," Journal of the International Phonetic Association, vol. 6, pp. 4-12, 1976.

[19] C. Mayo, A. Matthew, and R. Ladd, "Prosodic transcription of Glasgow English: an evaluation study of GlaToBI," in Proceedings of Intonation: Theory, Models, and Applications, Athens, Greece, September 18-20 1997, pp. 231-234.

[20] A. Cruttenden, "Intonational diglossia: a case study of Glasgow," Journal of the International Phonetic Association 37(3), pp. 257-274, 2007.

[21] C. Nance, S. Kirkham, and E. Groarke, "Intonational variation in Liverpool English," in Proceedings of the ICPhS XVIII, 2015.

[22] A. Cruttenden, "Mancunian intonation and intonational representation," Phonetica 58, pp. 3-80, 2001.

[23] P. Warren, Uptalk. Cambridge: Cambridge University Press, 2016
[24] P. Eckert, "The Whole Woman: Sex and Gender Differences in Variation," Language Variation and Change, vol. 1, pp. 245 268, 1989.

[25] R. Lakoff, Language and Woman's Place, New York: Harper \& Row, 1975.

[26] M. Liberman, "The phonetics of uptalk," Language Log, vol. 13, no. $09,2008$.

[27] A. Ritchart and A. Arvaniti, "The form and use of uptalk in Southern Californian English," in Proceedings of the Speech Prosody 2014.

[28] S. Wilhelm, “Quand les paroles s'envolent: réflexions sur les caractéristiques et la forme phonétique du High Rising Terminal en anglais contemporain," Anglophonia: French Journal of English Linguistics, vol. 20, 2015. Available: http://anglophonia.revues.org/591

[29] S. Wilhelm, "Towards a typological classification and description of HRTs in a multidialectal corpus of contemporary English," in Proceedings of Speech Prosody 2016.

[30] A. Cruttenden, Gimson's Pronunciation of English, 8th edition (1st edition Gimson 1962), London \& New-York: Routledge, 2014. 